\title{
Peran Mediasi Employee Engagement pada Pengaruh Talent Management Terhadap Employee Retention
}

\section{( The Role of Employee Engagement Mediation on the Effect of Talent Management on Employee Retention )}

Oleh:

\author{
Muhamad Ekhsan ${ }^{1)}$; Muhamad Taopik ${ }^{2)}$ \\ Universitas Pelita Banngsa1,2) \\ muhamad.ekhsan@pelitabangsa.ac.id; muhamadtaopik2@gmail.com
}

Submit: 23 Nov $2020 \quad$ Review: 07 Dec $2020 \quad$ Accept: 16 Dec $2020 \quad$ Publish: 22 Dec 2020

\begin{abstract}
ABSTRAK
Tujuan dari penelian ini adalah untuk mengetahui apakah ada pengaruh talent management terhadap employee retention yang di mediasi employee engagement. Objek penelitian pada PT Matahari Putra Prima,Tbk cikarang. Penelitian dilakukan dengan menggunakan metode kuantitatif dengan software SEM Smart PLS sebagai alat analisis. Jumlah sampel yang diperoleh dengan teknik pengambilan sampel secara random sampling menggunakan rumus slovin berjumlah 84 responden. Pengumpulan data dilakukan melalui menggunakan google form dalam mengisi survei online. Metode analisis data yang digunakan adalah uji $R$ - square,Bootstrapping,Path Coefficient, dan Specific indirect effects. Hasil penelitian ini menunjukan bahwa talent management tidak berpengaruh terhadap employee retention,talent management memiliki pengaruh positif dan signifikan terhadap engagement,employee engagement mimiliki pengaruh positif dan signifikan terhadap employee retention,employee engagement mampu memberikan pengaruh positif dalam memediasi hubungan talent management terhadap employee retention pada karyawan pt matahari putra prima, tbk.
\end{abstract}

Kata kunci:

Talent Management, Employee Retention, Employee Engagement.

\section{ABSTRACT}

The purpose of this study was to determine whether there is an effect of talent management on employee retention mediated by employee engagement. The object of research at PT Matahari Putra Prima, Tbk cikarang. The research was conducted using quantitative methods with SEM Smart PLS software as an analysis tool. The number of samples obtained by using a random sampling technique using the Slovin formula was 84 respondents. Data collection was carried out using google form in filling out online surveys. The data analysis method used is the R-square test, Bootstrapping, Path Coefficient, and Specific indirect effects. The results of this study indicate that talent management has no positive and significant effect on employee retention, talent management has a positive and significant effect on engagement, employee engagement has a positive and significant impact on 
employee retention, employe engagement is able to have a positive influence in mediating the relationship between talent management and employees. Retention to employees of PT Matahari Putra Prima, Tbk.

\section{Keywords:}

Talent Management,Employee Retention, Employee Engagement

\section{PENDAHULUAN}

Turnover intention merupakan keinginan karyawan untuk mengundurkan diri karena berbagai alasan, salah satunya untuk mendapatkan pekerjaan atau jabatan yang lebih baik. Adanya niat untuk pergi tidak hanya menghilangkan bakat organisasi, tetapi juga menghambat kelancaran organisasi (Igbaria \& Greenhaus, 1992). Perputaran dapat berakibat fatal bagi organisasi, karena perusahaan mungkin menghadapi kekurangan tenaga ahli di pasar tenaga kerja dan menyebabkan biaya pendidikan tinggi bagi para pemula.

Laporan Gaji dan Ketenagakerjaan Asia Tenggara 2016 menyatakan bahwa karena kurangnya kandidat dengan keterampilan dan kualifikasi yang sesuai, pergantian karyawan yang tinggi dan inflasi upah yang tinggi akan menjadi karakteristik pasar kerja Indonesia tahun depan. Pekerja Indonesia lebih cenderung berganti pekerjaan. $50 \%$ dari mereka bermigrasi untuk menghasilkan uang, sementara hanya 15\% melakukannya untuk memperluas pengalaman mereka. Indonesia percaya bahwa karena biaya tenaga kerja yang relatif rendah dan meningkatnya permintaan untuk infrastruktur, industri teknik dan manufaktur tumbuh. Oleh karena itu, selain keterampilan komunikasi yang baik dan pengalaman bekerja di perusahaan multinasional, dibutuhkan juga talenta dengan keterampilan teknis yang kuat.

Laporan tingkat turnover di Indonesia (Michael Page, 2015), dapat di lihat pada gambar 1.

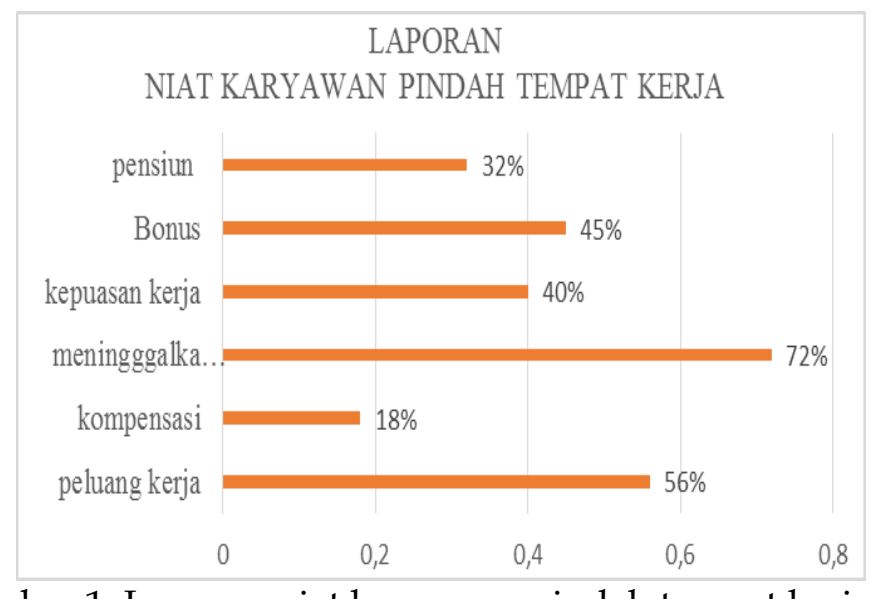

Gambar 1. Laporan niat karyawan pindah tempat kerja

Sumber: Michael page, (2015)

Menurut karyawan yang menanggapi survei niat karyawan Michael Page
Indonesia 2015, hasil penelitian menunjukkan bahwa 56\% karyawan 
menyatakan mereka menganggap peluang kerja saat ini baik atau sangat baik. Sebanyak 18\% karyawan yang disurvei mengungkapkan bahwa mereka berharap ketika pindah ke posisi baru, gaji mereka akan meningkat $21 \%-25 \%$. 72\% karyawan mengatakan mereka berencana untuk meninggalkan posisi mereka saat ini dalam 12 bulan ke depan. Di antara responden yang menyatakan ketidakpuasan dengan pekerjaan mereka, $40 \%$ memilih manajemen sebagai kontributor utama mereka. Untuk 45\% karyawan yang disurvei, penghargaan ekonomi tertinggi adalah bonus, sementara 32\% memilih pensiun.

Mempertahankan karyawan adalah fungsi dan daya saing perusahaan. Menjaga karyawan yang bertalenta dan terampil itu penting dalam persaingan. Saat bersaing dengan pesaing, perusahaan membutuhkan pengetahuan dan keterampilan karyawan. Perusahaan berkembang dan belajar melalui karyawan untuk mencapai pengembangan karyawan yang berkelanjutan. Alias et al (2014), menjelaskan bahwa proses pencapaian tujuan kinerja organisasi dipengaruhi oleh tingkat retensi pegawai. Menurut Mathis (2006) retensi karyawan mengacu pada kemampuan dan upaya manajemen organisasi untuk mendorong karyawan bertalenta memiliki tingkat loyalitas yang tinggi. Keinginan individu untuk bertahan lama di perusahaan bergantung pada berapa banyak karyawan yang dipertahankan.

Hughes (2008) menunjukkan bahwa efektivitas retensi karyawan dipengaruhi oleh beberapa faktor, yaitu manajemen bakat, rekrutmen karyawan, dan keterlibatan karyawan. Menurut Hughes (2008), jika manajemen bakat efektif, retensi karyawan juga akan beroperasi secara efektif. Manajemen bakat adalah bagian yang sangat diperlukan dalam melibatkan karyawan dalam suatu organisasi. Mangusho (2015) menjelaskan bahwa setiap karyawan menginginkan pekerjaan sesuai dengan potensinya.Ketika perusahaan dapat menempatkan mereka dalam pekerjaan dan bidang sesuai dengan bakat dan kemampuannya, karyawan akan merasa antusiasme. Jika terjadi ketimpangan antara penerapan talent management pada perusahaan yang dikelola dengan baik maka cost akan berkurang.

Lewis (2006) dalam penelitiannya menunjukkan bahwa manajemen bakat mendorong tingkat retensi karyawan yang tinggi melalui upaya untuk mengelola aliran sumber daya manusia di berbagai departemen organisasi. Holland (2007) menunjukkan bahwa manajemen bakat adalah proses mengelola sumber daya manusia dan membimbing bakat karyawan. Hughes (2008) menunjukkan bahwa distribusi talenta karyawan mendorong karyawan untuk bertahan dalam organisasi sehingga organisasi dapat bersaing dalam menghadapi lingkungan persaingan serta menunjukkan bahwa manajemen bakat adalah konsep multifaset, yang berfokus pada sumber daya manusia, perencanaan, termasuk perekrutan karyawan dan retensi karyawan. Pimapunsri (2013) dalam penelitiannya menjelaskan bahwa rencana manajemen bakat telah digunakan di perusahaan, dan sebagian besar kegiatan rencana manajemen bakat terkait dengan kegiatan sumber daya manusia, termasuk rekrutmen, seleksi, pengembangan, evaluasi, retensi, dan perencanaan suksesi.

Manajemen bakat mengacu pada proses sistematis, dinamis, untuk menemukan, mengembangkan dan mempertahankan bakat. Tingginya tingkat retensi pemberi kerja bergantung pada 
keberhasilan organisasi dalam mengelola bakat karyawan, yang membantu Organisasi mengurangi tingkat keluar masuk karyawan yang tinggi karena ketidakcocokan personel. pekerjaan.

Glen (2006) mengemukakan bahwa employee engagement merupakan faktor yang mempengaruhi retensi karyawan di perusahaan. Organisasi dapat mencapai profitabilitas tinggi dengan dukungan manajemen bakat yang efektif dan keterlibatan karyawan (Schaufeli et al., 2002). Keterlibatan karyawan didefinisikan sebagai keadaan insentif positif, Berisi ciriciri ketekunan, semangat dan pekerjaan secara keseluruhan (Alias et al., 2014). Hubungan positif antara talent management dan employee retention di perusahaan dipengaruhi oleh employee engagement. Tiwari (2013) dalam penelitiannya menunjukkan bahwa employee engagement dapat meningkatkan efisiensi manajemen talenta dalam suatu organisasi dan meningkatkan retensi karyawan. Karyawan perusahaan akan ditahan ketika mereka dihargai oleh pemimpin mereka dan berkomitmen untuk berkontribusi pada tujuan organisasi (Davies \& Crane, 2010).

Aljunaibi (2014) mengemukakan bahwa karyawan yang dihargai karena keberadaannya sendiri, dihargai dan diakui akan lebih termotivasi dan meningkatkan dirinya dalam bekerja. Jika karyawan berpikir bahwa perusahaan dapat memberikan mereka rasa nyaman dalam bekerja, tetapi karyawan tersebut tidak dihargai oleh perusahaan, maka mereka akan berpartisipasi. Peningkatan keterikatan karyawan akan berdampak signifikan terhadap produktivitas, dan peningkatan retensi karyawan (Dhanalakshmi \& Gurunathan, 2014). Penelitian oleh Albrecht (2010) menunjukkan bahwa keterlibatan karyawan digambarkan sebagai keinginan anggota organisasi untuk bekerja di sebuah perusahaan. Peran employee engagement juga dapat membantu karyawan mengenali dan mengekspresikan diri secara emosional di tempat kerja.

Retensi karyawan merupakan penelitian yang sudah banyak dilakukan. Penelitian sebelumnya yang dilakukan oleh beberapa peneliti memiliki hasil penelitian yang berbeda-beda, sehingga masih perlu dilakukan penelitian lebih lanjut untuk mengisi gap penelitian tersebut. Julianda (2020) menjelaskan bahwa dalam penelitiannya menemukan bahwa talent management tidak berpengaruh terhadap employee retention pada pt telekomunikasi indonesia kota metro. Hasil penelitian Gede (2019) menemukan bahwa talent management berdampak negatif terhadap turnover yang dilakukan di setiap sektor perbankan. Talent management tidak berpengaruh signifikan terhadap employee engagement pada PT Berlian Jasa Terminal Indonesia Surabaya yang bergerak di bidang pelayanan publik (prameswara nur kartikasari, 2018). Penelitian yang dilakukan oleh Yong (2017) menemukan bahwa employee engagement tidak berpengaruh signifikan terhadap tingkat retensi karyawan perusahaan jasa perbankan.

Objek penelitian dalam penelitian ini adalah PT Matahari Putra Prima, Tbk, salah satu industri ritel modern di Cikarang. PT Matahari Putra Prima,Tbk merupakan retail Lippo Group yang menguasai pasar, mereka memiliki gerai di seluruh Indonesia, seperti Hypermart, Hyfresh , Foodmart Fresh, Foodmart Primo, Foodmart Xpress, Smart Club, Boston, dll. Yang menyediakan produk produk berkualitas tinggi dengan harga kompetitif bagi konsumen Indonesia. 
Fenomena dalam penelitian ini terkait tingginya tingkat turnover yang terjadi pada PT Matahari Putra Prima Tbk selama 4 tahun. Banyak karyawan yang keluar. Alasannya karyawan mengundurkan diri secara sukarela atau perusahaan memutuskan hubungan kerja. Hal ini sejalan dengan tingkat retensi karyawan PT Matahari Putra Prima,Tbk saling terkait, dapat dilihat pada gambar 2 grafik employee retention.

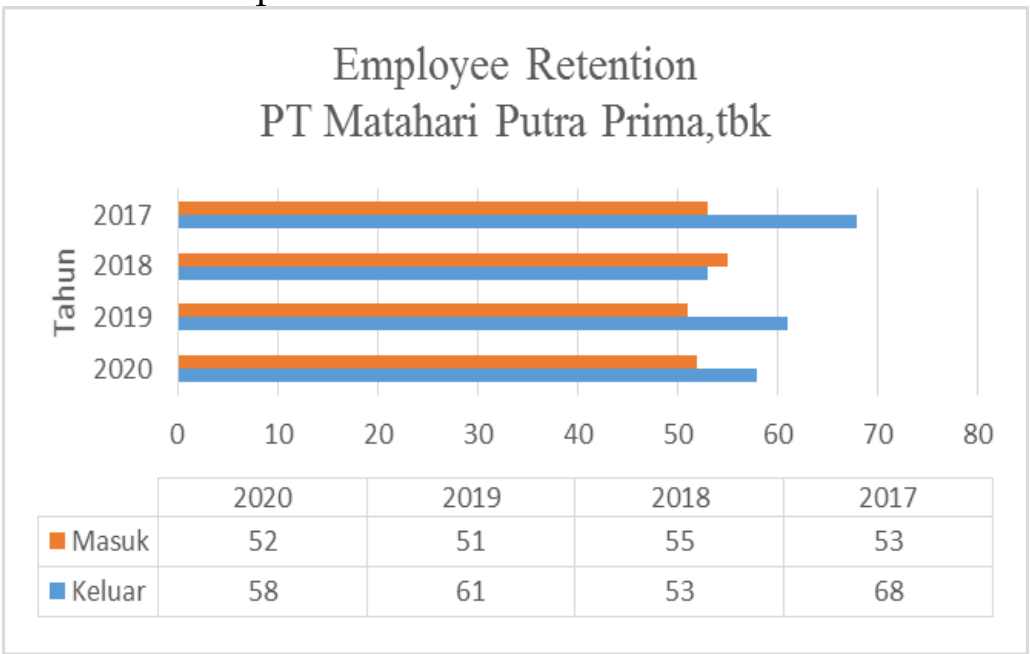

\section{Gambar 2. Grafik Employee retention pt matahari putra prima,tbk}

Sumber : hrd pt matahari putra prima,,TBK. 2020

Menurut tingkat retensi karyawan PT Matahari Putra Prima, tbk, jumlah karyawan keluar cukup besar. Pada tahun 2017 tingkat retensi karyawan tertinggi adalah 68 karyawan. Pada tahun 2018, tingkat retensi karyawan terendah adalah 53 karyawan. Secara keseluruhan kejadian ini tentunya akan berdampak pada pengaruh setiap departemen perusahaan. Atas dasar uraian tersebut maka tujuan penelitian ini adalah untuk mengetahui pengaruh langsung talent management terhadap employee retention, talent management terhadap employee engagement, employee engagement terhadap employee retention dan untuk mengetahui pengaruh tidak langsung talent management terhadap employee retention melalui employee engagement

\section{METODE PENELITIAN Sampel Penelitian}

Populasi penelitian ini adalah 107 karyawan PT Matahari Putra Prima,Tbk. Sampel penelitian adalah karyawan PT Matahari Putra Prima,Tbk yang berjenis kelamin laki-laki dan perempuan yang diambil dengan rumus Slovin dengan margin eror 5\% diperoleh 84 orang. Teknik pengambilan sample menggunakan google form dalam mengisi survei online. Metode yang digunakan adalah metode kuantitatif dengan menggunakan software SEM Smart PLS sebagai alat analisis. Untuk mengetahui pengaruh talent management terhadap employee retention, pengaruh talent management terhadap employee engagement, pengaruh employee engagement terhadap employee retention, pengaruh talent management terhadap employee retention yang dimediasi oleh employee engagement. 
Pengembangan Hipotesis

Hubungan Talent Management terhadap Employee Retention

Penelitian Davis et al. (2007) menjelaskan bahwa langkah terpenting dalam manajemen bakat adalah mempertahankan karyawan berbakat dalam organisasi. Karyawan berbakat dianggap sebagai investasi utama dalam organisasi dan memberikan alasan mengapa perusahaan perlu mempertahankan mereka dalam organisasi. Hal yang sama dalam penelitian Kataike (2013) membuktikan bahwa terdapat hubungan yang positif dan penting antara talent management dengan retensi karyawan. Berdasarkan uraian penelitian diatas, maka dikemukakan hipotesis sebagai berikut:

H1: Talent management berpengaruh posited dan signifikan terhadap employee retention

Hubungan Talent Management terhadap Emloyee Engagement

Aljunaibi (2014) membuktikan bahwa talent management memiliki korelasi positif dan berpengaruh signifikan terhadap employee engagement. Hal yang sama dalam penelitian Thakur (2015) membuktikan bahwa talent management memiliki impact positive dan signifikansi terhadap employee engagement. Berdasarkan uraian penelitian diatas, maka dikemukakan hipotesis sebagai berikut:

$\mathrm{H} 2$ : Talent management berpengaruh positif dan signifikan terhadap employee engagement

\section{Hubungan Employee Engagement terhadap Employee Retention}

Penelitian Bhattacharya

membuktikan bahwa employee engagement dan employee retention memiliki hubungan yang kuat dan positif. Dash (2013) membuktikan dalam penelitiannya bahwa employee engagement berpengaruh positif terhadap retensi karyawan. Oladapo (2014) mengemukakan hal yang sama, yaitu terjalin hubungan positif antara employee engagement dan variabel retensi karyawan. Berdasarkan uraian penelitian diatas, maka dikemukakan hipotesis sebagai berikut:

H3 : Employee Engagement berpengaruh positif dan signifikan terhadap employee retention

Hubungan Talent management terhadap employee retention yang di mediasi employee engagement

Penelitian Chitsaz-isfahani menunjukkan bahwa employee engagement sebagai variabel perantara dapat membentuk hubungan positif antara talent management dan employee retention. Penelitian Sadana (2014) menekankan bahwa employee engagement dapat memediasi dampak positif dari talent management terhadap retensi karyawan. Nursanti (2019) membuktikan bahwa employee engagement dapat memediasi variabel talent management dan employee retention. Berdasarkan uraian penelitian diatas, maka dikemukakan hipotesis sebagai berikut:

H4: Employee engagement memediasi pengaruh talent management terhadap employee retention.

\section{Desain Penelitian}

Berdasarkan kajian teori dan review hasil penelitian terdahulu yang telah dipaparkan, dapat disimpulkan bahwa peningkatan employee retention secara umum dipengaruhi oleh berbagai faktor. Penelitian ini terfokus pada talent management, employee engagement dan employee retention. Berdasarkan uraian tersebut, maka dapat dirumuskan desain 
penelitian sebagaimana tertera pada gambar 3.

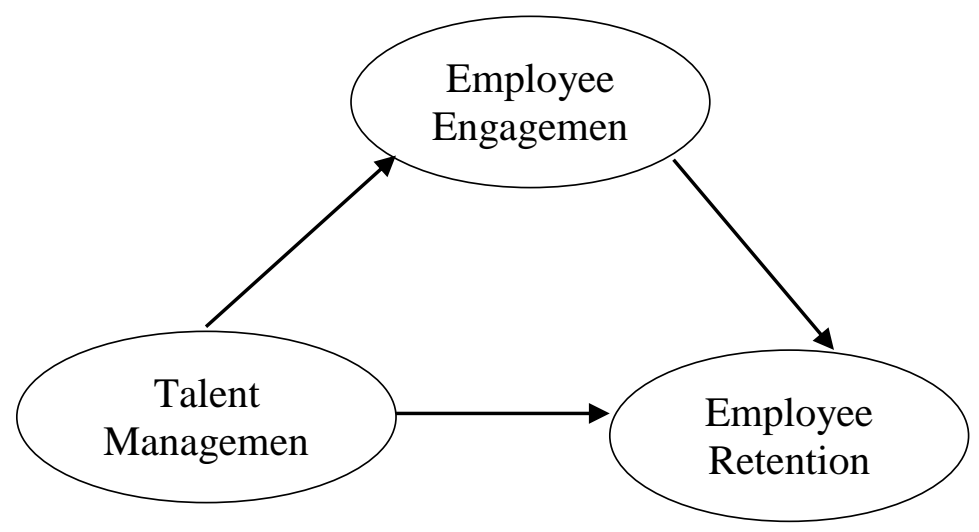

Gambar 3. Design Penelitian

\section{Operasionalisasi Variabel}

Seperti yang ditunjukkan pada Tabel 1, setiap variabel diukur dengan menggunakan indikator yang berbeda.

Tabel 1. Operasionalisasi Variabel

\begin{tabular}{lll}
\hline \multicolumn{1}{c}{ VARIABEL } & \multicolumn{1}{c}{ INDIKATOR } & \multicolumn{1}{c}{ SKALA } \\
\hline Talent Management & Rekrutmen & Interval 1-5 \\
(Oladapo, 2014) & Kinerja Manajemen & \\
& Perencanaan Sukses & \\
& Pelatihan & \\
& Mempertahankan & \\
\hline Employee Engagement & Pengakuan Kerja & Interval 1-5 \\
(Bhattacharya, 2015) & Mendengarka Pendapat & \\
& Merasa di hargai & \\
& Penghargaan & \\
\hline Employee Retention & Kebanggaan & Interval 1-5 \\
(Isfahani \& Boustani, 2014) & Pekerjaan Menarik & \\
& Perkembangan Karir & \\
& Hubungan karyawan & \\
& Pengupahan adil & \\
& Dukungan Menajemen & \\
\hline
\end{tabular}

Sumber: peneliti (2020)

\section{Metode Analisis}

Data uji yang digunakan dalam penelitian ini meliputi uji R- square,
Bootstrapping, Path Coefficient, dan Specific indirect effects. 
HASIL PENELITIAN DAN

\section{PEMBAHASAN}

\section{Hasil Penelitian}

Pengujian ini menguji model struktural dengan melihat nilai R-square yang Merupakan hasil uji kesesuaian Model Talent Management terhadap Employee Retention nilai R-square nya adalah 0,754 yang dapat di jelaskan sebagai variabelitas struktural Tingkat Employee Retention dapat dijelaskan oleh variabel struktur Talent Management 75,4\% dan 24,6
\% dijelaskan oleh variabel lain di luar penelitian ini. Model dampak lainnya adalah Nilai variabel Employee Engagement ditampilkan sebesar 0,722, jadi bisa di jelaskan bahwa 72,2 \% menggunakan variabel dependen yaitu talent management dan employee retention untuk membangun employee engagement dan 27,8 \% di jelaskan oleh variabel lain di luar penelitian ini.Hal tersebut dapat dilihat pada tabel dibawah ini:

Tabel 2. hasil uji R square

\begin{tabular}{ll}
\hline & R Square \\
\hline Employee Engagement & 0.722 \\
\hline Employee Retention & 0.754
\end{tabular}

Sumber: data peneliti yang diolah(2020)

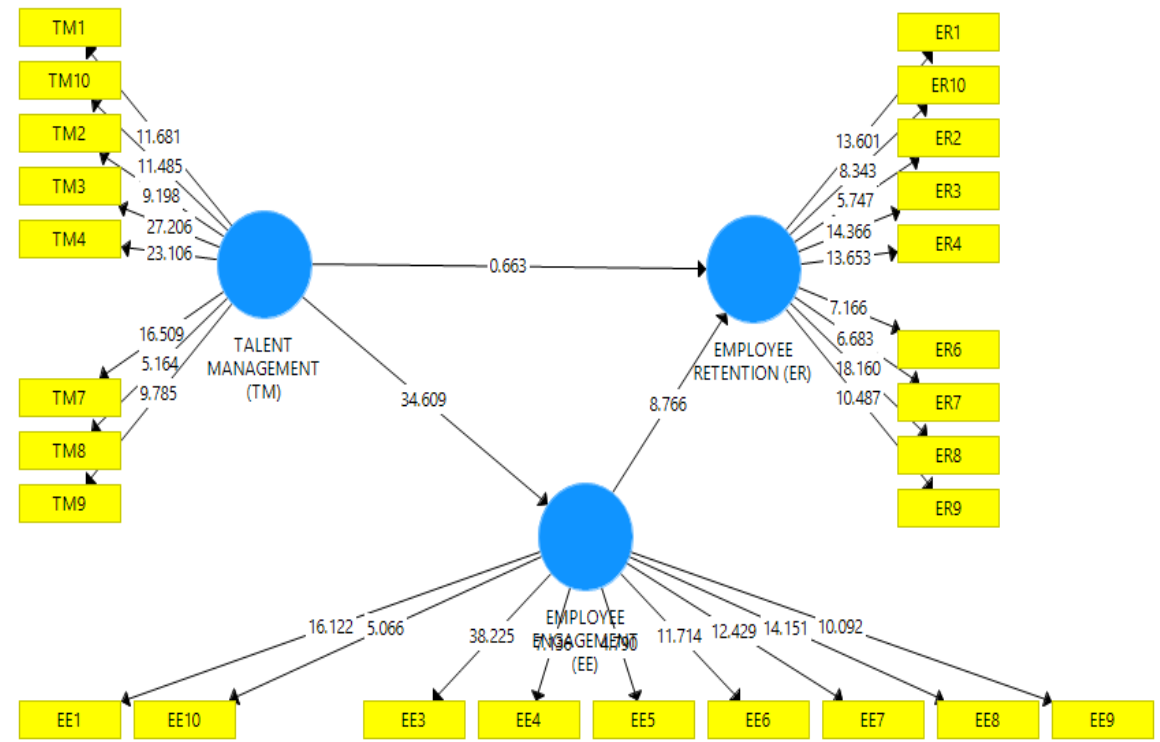

Gambar 4 Output Bootstrapping

Sumber: data Peneliti yang di olah(2020)

Setelah dilakukan uji deterministik, Intelligent PLS 3.0 dipandu untuk melakukan analisis jalur guna mengetahui hubungan kausal antara variabel eksogen dan variabel endogen, sehingga diperoleh prediksi dari hasil analisis jalur pada model. 
Nilai-nilai yang diestimasi untuk hubungan jalur di dalam model struktural harus dievaluasi dalam perspektif kekuatan dan signifikansi hubungan. Signifikansi hubungan dapat diperoleh dengan cara melakukan uji Bootstraping. Nilai yang dihasilkan dari uji Bootstraping adalah berupa nilai t-hitung yang kemudian akan dibandingkan dengan nilai t-table. Jika t-hitung lebih besar dari pada $\mathrm{t}$ table $(1,96)$ pada taraf nilai alpha $5 \%$, maka nilai estimasi jalur tersebut dapat dikatakan signifikan.

Tabel 3. Hasil uji Path Coefficient

\begin{tabular}{lccccc}
\hline & $\begin{array}{c}\text { Original } \\
\text { sample }\end{array}$ & $\begin{array}{c}\text { Sample } \\
\text { mean }\end{array}$ & $\begin{array}{c}\text { Standard. } \\
\text { Devisiation }\end{array}$ & T statistics & P \\
values
\end{tabular}

Di Jelaskan pengaruh langsung menurut path coefficient pada Tabel 3, kemudian Tabel 4 secara khusus menunjukkan pengaruh tidak langsung

Tabel 4. Specific Indirect Effects

\begin{tabular}{lccccc}
\hline & $\begin{array}{c}\text { Original } \\
\text { sample }\end{array}$ & $\begin{array}{c}\text { Sample } \\
\text { mean }\end{array}$ & $\begin{array}{c}\text { Standard. } \\
\text { Devisiation }\end{array}$ & $\begin{array}{c}\text { T } \\
\text { statistics }\end{array}$ & $\begin{array}{c}\text { P. } \\
\text { Values }\end{array}$ \\
\hline $\begin{array}{l}\text { Talent Management->Employee } \\
\text { Engagement->Employee }\end{array}$ & 0.682 & 0.702 & 0.084 & 8.150 & 0.000 \\
Retention & & & & & \\
$\begin{array}{l}\text { Sumber:data peneliti yang diolah(2020) } \\
\text { Sumber }\end{array}$ & & & & &
\end{tabular}

Hasil dari uji path coefficients pada variabel talent management memiliki nilai $t$ hitung sebesar 0,663, jika dibandingkan dengan $\mathrm{t}$ table $(1,96)$ maka nilai $\mathrm{t}$ hitung tersebut lebih kecil dari pada $t$ table sehingga dapat disimpulkan bahwa talent management tidak berpengaruh terhadap employee retention. Nilai koefisien jalur ini didapat dengan cara membandingkan nilai $p$ values dengan nilai apha $(0,050)$ Nilai $\mathrm{p}$ values variabel talent management memiliki besaran nilai 0,508 maka variabel tersebut tidak berpengaruh terhadap employee retention. Maka dapat disimpulkan bahwa variabel talent management tidak berpengaruh terhadap employee retention pada karyawan pt matahri putra prima,tbk, jadi hipotesis pertama $(\mathrm{H} 1)$ di tolak.

Hasil dari uji path coefficients pada variabel talent management memiliki nilai $\mathrm{t}$ hitung sebesar 34,609. Jika dibandingkan dengan $\mathrm{t}$ table $(1,96)$ maka nilai $\mathrm{t}$ hitung tersebut lebih besar dari pada $t$ table 
sehingga dapat disimpulkan bahwa talent management memiliki pengaruh yang signifikan terhadap employee engagement. Nilai $p$ values pada variabel talent management memiliki besaran nilai 0,000 maka variabel tersebut memiliki pengaruh signifikan terhadap employee engagement. Untuk mengecek pengaruh yang positif atau negatif maka perlu dicek nilai dari original sampel pada variabel tersebut. Variabel talent management memiliki nilai original sampel 0,850 yang berarti estimasi jalur dari variabel talent management terhadap employee engagement memiliki jalur positif dengan nilai 0,850 . Maka dapat disimpulkan bahwa variabel talent management berpengaruh positif signifikan terhadap employee engagement pada karyawan pt matahari putra prima,tbk, jadi hipotesis kedua (H2) diterima.

Hasil dari uji path coefficients pada variabel employee engagement memiliki nilai t hitung sebesar 8,766. Jika dibandingkan dengan $\mathrm{t}$ table $(1,96)$ maka nilai $\mathrm{t}$ hitung tersebut lebih besar dari pada $t$ table sehingga dapat disimpulkan bahwa employee engagement memiliki pengaruh yang signifikan terhadap employee retention. Nilai $\mathrm{p}$ values pada variabel employee engagement memiliki besaran nilai 0,000 maka variabel tersebut memiliki pengaruh signifikan terhadap employee retention. Untuk mengecek pengaruh yang positif atau negatif maka perlu dicek nilai dari original sampel pada variabel tersebut. Variabel talent management memiliki nilai original sampel 0,803 yang berarti estimasi jalur dari variabel talent management terhadap employee engagement memiliki jalur positif dengan nilai 0,803.Maka dapat disimpulkan bahwa variabel employee engagement berpengaruh positif signifikan terhadap employee retention pada karyawan pt matahari putra prima,tbk, jadi hipotesis kedua (H3) diterima.
Hasil dari uji path coefficients pada variabel employee engagement sebagai variabel mediasi memiliki nilai $t$ hitung sebesar 8.150 Jika dibandingkan dengan $\mathrm{t}$ table $(1,96)$ maka nilai $\mathrm{t}$ hitung tersebut lebih besar dari pada $t$ table sehingga dapat disimpulkan bahwa employee engagement memiliki pengaruh yang signifikan dalam memediasi talent management terhadap terhadap employee retention. Nilai $\mathrm{p}$ values pada variabel employee engagement memiliki besaran nilai 0,000 maka variabel tersebut memiliki pengaruh yang signifikan dalam memediasi talent management terhadap employee retention. Untuk mengecek pengaruh yang positif atau negatif maka perlu dicek nilai dari original sampel pada variabel tersebut. Variabel employee engagement memiliki nilai original sampel 0,682 yang berarti estimasi jalur dari variabel employee engagement dalam memediasi talent management terhadap employee retention memiliki jalur positif dengan nilai 0,682.Maka dapat disimpulkan bahwa variabel employee engagement berpengaruh positif signifikan dalam memediasi talent management terhadap employee retention pada karyawan pt matahari putra prima,tbk, jadi hipotesis kedua (H4) diterima.

\section{Pembahasan}

Variabel Talent management tidak berpengaruh terhadap variabel employee retention. Artinya peningkatan talent management secara positif searah terhadap employee retention akan tetapi tidak berpengaruh signifikant terhadap employee retention. Penelitian ini sejalan dengan penelitian Julianda (2020) yang menunjukan bahwa talent management tidak berpengaruh terhadap employee retention. Berdasarkan hasil penelitian yang dilakukan, peningkatan talent management pada pt matahari putra 
prima,tbk dapat meningkatkan employee retention namun dampaknya tidak signifikan. Namun demikian, manajemen tetap melakukan peningkatan talent management terhadap karyawannya melalui evaluasi dari hasil yang sudah ada.

Varabel Talent management ber pengaruh yang positif dan signifikan terhadap employee engagement.Artinya semakin tinggi variabel talent management maka semakin tinggi pula employee engagementnya.penelitian ini sejalan dengan penelitian (Irmawaty \& Hamdani, 2016) menunjukkan bahwa, ada hubungan yang signifikan antara talent management dengan employee engagement. (Aljunaibi, 2014)membuktikan bahwa, talent management mempunyai hubungan positif dan berpengaruh signifikan terhadap employee engagement.karyawan Partisipasi efektif mendorong rangsangan lingkungan organisasi, seperti Memberikan pengembangan dan pembelajaran, dukungan, apresiasi dan Diakui dalam program manajemen bakat terapan perusahaan (Glen, 2006)

Variabel Employee engagement berpengaruh yang positif dan signifikan terhadap employee retention. Penelitian ini sejalan dengan penelitian (Alias et al., 2014) membuktikan bahwa dalam penelitiannya terdapat hubungan yang signifikan dan positif antara employee engagement dengan employee retention. Penelitian yang dilakukan Bhattacharya (2015) membuktikan bahwa, employee engagement ditemukan memiliki signifikansi yang kuat dan hubungan positif pada employee retention. Hal yang sama dinyatakan pada penelitian Oladapo (2014) yang menjelaskan bahwa terciptanya hubungan positif antara variabel employee engagement dengan employee retention.

Hasil uji mediasi menunjukan employee engagement dapat memberikan pengaruh positif dalam memediasi talent management pada employee retention. Artinya,hubungan positif antara talent management dan employee retention mampu di mediasi oleh employee engagement. Penelitian ini sejalan dengan penelitian yang dilakukan oleh Chitsaz- Isfahani (2014) menunjukan bahwa employee engagement sebagai variabel mediasi mampu menciptakan hubungan positif antara talent management terhadap employee retention. Alias et al (2014) menunjukan bahwa employee engagement merupakan variabel mediasi antara talent management dengan employee retention. Kamil (2015) dalam penelitiannya membuktikan bahwa, employee engagement merupakan variabel yang memediasi hubungan pada talent management terhadap employee retention. Keterlibatan sebagai mediator dalam hubungan antara praktik manajemen talenta dan retensi karyawan membuatnya sangat berharga untuk memperluas bukti dalam penelitian ini.

\section{KESIMPULAN}

Berdasarkan pembahasan hasil penelitian di atas, dapat disimpulkan bahwa talent management tidak berpengaruh positif dan signifikan terhadap retensi karyawan, talent management berpengaruh positif dan signifikan terhadap employee engagement, dan employee engagement berpengaruh positif dan signifikan terhadap retensi karyawan. Dampak keterikatan karyawan dapat berdampak positif pada retensi karyawan. PT Matahari Putra Prima di Tbk memediasi hubungan antara manajemen bakat dan retensi karyawan.

Saran yang dapat diberikan kepada pihak pt matahari putra prima,tbk sebaiknya perusahaan lebih selektif dalam merekrut karyawan yang berbakat dan 
memberikan penghargaan kepada mereka, sehingga membuat mereka merasa akan loyal kepada perusahaan.Selain itu, sebaiknya perusahaan meningkatkan dan menghilangkan beberapa aturan perusahaan yang meyakini bahwa kurang ada dukungan bagi karyawan dalam bekerja dengan aturan perusahaan yang baru,agar karyawan dapat bekerja secara optimal dan perusahaan juga perlu memberikan kenyaman dan dukungan kepada karyawan dalam bekerja supaya karyawan lebih giat lagi dalam bekerja.Perusahaan perlu memberikan apresiasi atas pekerjaan karyawan.

\section{“DAFTAR PUSTAKA}

Albrecht, S. L. (2010). Employee engagement: 10 key questions for research and practice.

Alias, N. E., Noor, N. M., \& Hassan, R. (2014). Examining the Mediating Effect of Employee Engagement on the Relationship between Talent Management Practices and Employee Retention in the Information and Technology (IT) Organizations in Malaysia. Journal of Human Resources Management and Labor StudiesOnline) Journal of Human Resources Management and Labor Studies, 2(22), 227-242. https:/ / doi.org/10.15640/jhrmls

Aljunaibi, M. M. (2014). Talent management and employee engagement. The British University in Dubai (BUiD).

Bhattacharya, Y. (2015). Employee Engagement as a Predictor of Seafarer Retention: A Study among Indian Officers. Asian Journal of Shipping and Logistics, 31(2), 295-318. https://doi.org/10.1016/j.ajsl.2015.06.007

Chitsaz-Isfahani, A., \& Boustani, H. R. (2014). Effects of talent management on employees retention: The mediate effect of organizational trust. International Journal of Academic Research in Economics and Management Sciences, 3(5), 114.

Dash, B. (2013). Employee engagement and HR initiatives:-A conceptual study. International Journal on Global Business Management \& Research, 1(2), 85.

Davies, I. A., \& Crane, A. (2010). Corporate social responsibility in small-and medium-size enterprises: investigating employee engagement in fair trade companies. Business Ethics: A European Review, 19(2), 126-139.

Davis, T., Cutt, M., \& Flynn, N. (2007). Talent assessment: A new strategy for talent management. Gower Publishing, Ltd.

Dhanalakshmi, R. V, \& Gurunathan, K. B. (2014). A study on talent management as a strategy to influence employee engagement and its affect on the organizational outcome. International Journal of Business and Administration Research Review, 2(4), 183-186.

Gede, I. K., \& Sunny, M. P. (2019). Pengaruh Leader Member Exchange, Empowerment, Talent Management Terhadap Turnover Intention. Widya Manajemen, 1(2), 113-137.

Glen, C. (2006). Key skills retention and motivation: the war for talent still rages and retention is the high ground. Industrial and Commercial Training.

Holland, P., Sheehan, C., \& De Cieri, H. (2007). Attracting and retaining talent: Exploring human resources development trends in Australia. Human Resource Development International, 10(3), 247-262. 
Hughes, J. C., \& Rog, E. (2008). Talent management: A strategy for improving employee recruitment, retention and engagement within hospitality organizations. International Journal of Contemporary Hospitality Management, 20(7), 743-757.

Igbaria, M., \& Greenhaus, J. H. (1992). Determinants of MIS employees' turnover intentions: a structural equation model. Communications of the ACM, 35(2), 34-49.

Irmawaty, I., \& Hamdani, M. (2016). PENGARUH TALENT MANAGEMENT TERHADAP PENGEMBANGAN KARIR PEGAWAI DI UNIVERSITAS TERBUKA. Jurnal Organisasi Dan Manajemen, 12(2), 97-104.

Isfahani, A. C.-, \& Boustani, H. (2014). Effects of Talent Management on Employees Retention: The Mediate Effect of Organizational Trust. International Journal of Academic Research in Economics and Management Sciences, 3(5), 114-128. https://doi.org/10.6007/ijarems/v3i5/1196

Julianda, T. (2020). PENGARUH TALENT MANAGEMENT DAN EMPLOYEE ENGAGEMENT TERHADAP EMPLOYEE RETENTION (pada karyawan PT. Telekomunikasi Indonesia Kota Metro). Universitas Muhammadiyah Metro.

Kamil, B. A. M. (2015). The Relationship of Talent Management and Succession Planning with Employee Retention in Higher Education Institutions: Roles of Career Development and Employee Engagement as Mediators. International Islamic University Malaysia.

Kataike, S. (2013). Relationship between talent management and employee retention in commercial banks in Kenya. University of Nairobi.

Lewis, R. E., \& Heckman, R. J. (2006). Talent management: A critical review. Human Resource Management Review. https:/ / doi.org/10.1016/j.hrmr.2006.03.001

Mangusho, Y. S., Murei, R. K., \& Nelima, E. (2015). Evaluation of talent management on employees performance in beverage industry: A case of Del Monte Kenya Limited. International Journal of Humanities and Social Science, 5(8), 191-199. https:/ / doi.org/10.1016/S0013-4686(02)00122-6

Mathis, L. R., \& Jackson, J. H. (2006). Manajemen sumber daya manusia (Human resource management). Jakarta, Salemba Empat.

Michael Page. (2015). 2015 Employee Intentions Report Indonesia. In Michael Page.

Nursanti, T. D., \& Then, T. (2019). The Influence of Job Resources Toward Employee Engagement and Its Impact On Turnover Intention of the Employees of PT Bank DKI. Jurnal Ilmu Manajemen E Ekonomika, 11(1), 1-9.

Oladapo, V. (2014). The impact of talent management on retention. Journal of Business Studies Quarterly, 5(3), 19.

Pimapunsri, P. (2013). Talent Management Practices: The Case of Companies in Thailand. GSTF International Journal of Law and Social Sciences, 2(2), 1-7.

PRAMESWARA NUR KARTIKASARI, M. (2018). Pengaruh Talent Management Dengan Perceived Organizational Support Sebagai Variabel Intervening Terhadap Employee Engagement Pada Pt Berlian Jasa Terminal Indonesia Surabaya. Jurnal Ilmu Manajemen (JIM), 6(4), 559-566.

Sadana, S., \& Vany, E. A. (2014). Pengaruh Employee Engagement dan Workplace Well-being terhadap Turnover Intention (Studi pada Kantor Akuntan Publik ABC E Rekan). 
Schaufeli, W. B., Salanova, M., González-Romá, V., \& Bakker, A. B. (2002). The measurement of engagement and burnout: A two sample confirmatory factor analytic approach. Journal of Happiness Studies, 3(1), 71-92.

Thakur, M. (2015). Impact of Talent Management Practices on Employee Engagement and Employee Retention-A Study at Bokaro Steel Plant.

Tiwari, U., \& Shrivastava, D. (2013). Strategies and practices of talent management and their impact on employee retention and effectiveness. The International Journal Of Management, 2(4), 1-10.

Yong, P. C. (2017). The Role of Talent Management in Employee Retention. UTAR.

11 